\title{
Audiology
}

\section{Development of a novel Italian speech-in-noise test using a roving-level adaptive method: adult population-based normative data}

\author{
Sviluppo di un innovativo test audiometrico vocale nel rumore in italiano che utilizza \\ un metodo "roving-level" adattivo: dati normativi basati sulla popolazione adulta \\ P. CANZI ${ }^{1}$, M. MANFRIN ${ }^{1}$, G. LOCATELLI ${ }^{1}$, P. NOPP ${ }^{2}$, M. PEROTTI ${ }^{3}$, M. BENAZZO ${ }^{1}$ \\ ${ }^{1}$ Department of Otorhinolaryngology, IRCCS Policlinico San Matteo Foundation and University of Pavia, Italy; ${ }^{2}$ MED- \\ EL GmbH, Innsbruck, Austria; ${ }^{3}$ SS Otoprotesica, Implanting Center Regione Piemonte, Ospedale Civile "SS Antonio \\ and Biagio e C. Arrigo", Alessandria, Italy
}

\begin{abstract}
SUMMARY
In recent years the increasing development of hearing devices has led to a critical analysis of the standard methods employed to evaluate hearing function. Being too far from reality, conventional investigation of hearing loss based on pure-tone threshold audiometry and on mono/disyllabic word lists, presented in quiet conditions, has been shown to be inadequate. A speech-in-noise test using a roving-level adaptive method employs target and competing signals varying in level in order to reproduce everyday life speaking conditions and explore a more complete sound range. Up to now, only few roving-level adaptive tests have been published in the literature. We conducted a rovinglevel adaptive test in healthy Italian adults to produce new normative data on a language of Latin origin.
\end{abstract}

KEY WORDS: Speech-in-noise test $\bullet$ Roving-level adaptive test

\section{RIASSUNTO}

Negli ultimi anni, il crescente sviluppo di dispositivi acustici ha condotto a un'analisi critica dei metodi standard che sono stati impiegati per valutare la funzione uditiva. Gli esami audiologici tradizionali, basati sulla soglia audiometrica tonale e sulle liste di parole mono/ bisillabiche nel silenzio, si sono nel tempo dimostrati inadeguati perché troppo distanti dalla realtà. Un test audiometrico vocale nel rumore, che utilizza un metodo "roving-level" adattivo, adopera segnali target e segnali competitivi modificabili con lo scopo di riprodurre le condizioni di eloquio della vita quotidiana, quindi esplorare un più ampio range uditivo. A oggi, solamente pochi test "roving-level" adattivi sono disponibili in letteratura. Gli autori hanno condotto un test "roving-level" adattivo in adulti italiani sani, al fine di ottenere nuovi dati normativi in una lingua di origine latina.

PAROLE CHIAVE: Audiometria vocale nel rumore • Test "roving-level” adattivo

Acta Otorhinolaryngol Ital 2016;36:506-512

\section{Introduction}

In recent years the increasing development of hearing devices has led to a critical analysis of the standard methods employed to evaluate the hearing function. It is renowned that two main factors influence the outcomes of hearing aids: type and severity of hearing impairment and environmental acoustic characteristics. Clinical practice outlines that aid patients who are apparently homogeneous for anatomical and audiological features may report different hearing perception under the same fitting conditions ${ }^{12}$. Moreover, speech intelligibility involves complex perceptual processes that emphasise the need for audiological tests reflecting reality as much as possible ${ }^{3}$. Normal-hearing listeners show a natural and exceptional ability to select the target voice in a background of competing voices ${ }^{4}$. Being too far from reality, conventional investigation of hearing loss based on pure-tone thresholds and on mono/disyllabic word lists, presented in quiet conditions, has been shown to be inadequate ${ }^{5}$. In fact, the international diffusion of sentence-type speech-in-noise tests has witnessed the emerging necessity of a more accurate audiological assessment ${ }^{36-16}$. These tests have been conceived to explore speech communication in noisy settings at a fixed or varied signal-to-noise ratio (SNR) as an expression of two basic philosophies. Fixed SNR tests are easily adopted and are administered to assess performances at a specific SNR level established before the examination. The listener's abilities are evaluated in terms of percent intelligibility, thus showing meaningful results 
not only for the clinician, but for the tested patient as well. Nevertheless, outcomes are influenced by the presentation levels of the target speech and the noise of competition. When clinicians select SNR parameters, the measured results not only depend on subjective hearing, but also on the fixed SNR. For example, a really challenging or an easy SNR may lead, respectively, to under- or overestimate the status of the patient ${ }^{17} 18$. The introduction of adaptive tests has overcome the described limitations by reversing the investigation perspective. No longer the tester, but the performance of the patient himself determines the SNR conditions. In particular, either the target signal level (e.g. speech) or the competing signal level (e.g. noise) increases/decreases by a set amount, according to the correct answers given by the patient ${ }^{17} 18$. The test starts with an easy SNR level, and subsequently the SNR conditions vary depending on the accuracy of the preceding response until the subject correctly repeats $50 \%$ of speech signals. The SNR presentation level, which is necessary for a listener to correctly recognise the speech messages $50 \%$ of the time, defines the speech reception threshold (SRT). In comparison to the fixed SNR tests, outcomes provided by the adaptive ones are expressed in decibels instead of percent intelligibility and show a reduced risk of bias arising from the limits of the method used ${ }^{3}$. Many adaptive tests have been developed and all are characterised by a varied SNR, but typically either the target signal or the competing signal is fixed ${ }^{36-141619}$. It is self-evident that real life is much different: rarely do the speech signals or noise signals change while the other one remains unmodified, but all vary independently. Furthermore, each hearing device performs differently at different sound pressure levels in relation with its own specific input dynamic range. The effects of environmental noise and technical features of hearing aids on speech intelligibility should be detected as much as possible by hearing tests. A roving-level adaptive test employs target and competing signals varying in level in order to reproduce everyday life speaking conditions and to explore a more complete sound range. In particular, speech material is presented at a roving level and the noise is adapted depending on the number of correct words answered by the tester to obtain patients' SRT. Up to now, only few roving-level adaptive tests have been published ${ }^{20}$. The aim of our study was to introduce a novel Italian roving-level adaptive test to yield normative data in healthy Italian adults.

\section{Materials and methods}

We evaluated 50 native normal hearing Italian individuals ( 25 men and 25 women), aged between 23 and 50 years, showing a pure tone average (PTA) lower than $20 \mathrm{~dB} \mathrm{HL}$ at the frequencies of 500,1000,2000 and $4000 \mathrm{~Hz}$. To carry out the test, we employed the sentences developed by Cutugno, Prosser and Turrini ${ }^{21}$, selecting only those made up of 5 words, establishing 6 lists piloted for equal difficulty and composed of 20 sentences each. Basically, some specific criteria were adopted for the construction of the sentence: choice of the lexical items, morphosyntactic structures and phrasal constituents order. The aim was to develop simple sentences that are easily understood by persons of different age groups, regional origins and cultural level. Therefore, enigmatic and abstract terms (e.g. solitude, height) or uncommon words (e.g. plausible) were avoided. With regard to the verb tenses, their usage frequency was taken into account, as well as their morphophonological structure in relation to perceptibility criteria. Considering the decreasing frequency, the most commonly used indicative verb tenses were: simple present, present perfect, imperfect tense, simple future and simple past. Sentences were short and understandable, made up of a number of syllables between 9 and 13 (Table I). Lists 1, 2 and 3 were used for the test (overall 60 sentences), while lists 4,5 and 6 for the re-test (overall 60 sentences). The noise of competition applied was a cocktail party background. Sentences were separated by a 10 -second pause while the noise of competition remained uninterrupted. The exam was performed in a soundproof booth; each sound was sent through a loudspeaker set in front of the subject, at eye-level and 1.2-meter distance. Each subject could reply by means of a microphone without any comments related to the correct answer. The procedure consisted of 60 sentences presented with a noise of competition. It lasted 14 minutes and was administered twice with a 30-minute break, in order to obtain an average result. Overall, each subject was submitted to a test and a re-test, and was instructed to repeat aloud completely or partially all the sentences heard or understood. During the test, speech material was randomly roved: sentences were casually organised in 20 groups of three sentences (overall 60 sentences) and each of the three sentences composing a triplet was casually presented at $55 \mathrm{~dB} \mathrm{HL}, 65 \mathrm{~dB} \mathrm{HL}$, or $75 \mathrm{~dB}$ HL. Within each triplet all three levels were used once, the test started at $+10 \mathrm{~dB}$ SNR with an easy competing signal and the noise level ("cocktail party" background) changed according to Table II and Table III. In particular, SNR varied across presentation levels and the SNR level was reduced progressively depending on the accuracy of the preceding response, until a conversion point that allowed calculation of the SRT value at which the subject was able to understand $50 \%$ of the sentences. The noise variation index ranged $\pm 5 \mathrm{~dB}$ HL from the 1 st to the 5 th triplet and ranged $\pm 2 \mathrm{~dB}$ HL from the 6 th to the 20th triplet. The three presentation levels of the signal (speech) and the SNR conditions were selected to represent the range of speech levels that may typically be encountered in everyday life. In particular, $55 \mathrm{~dB}$ HL corresponds to a comfortable conversational speech level, while $75 \mathrm{~dB}$ HL represents the limit within which a proper hearing aid fitting can result beneficial in terms of auditory perception (hearing loss $>75 \mathrm{~dB}$ represents the selection criteria for cochlear implantation). 
Table I. Lists of sentences used in the adaptive speech in noise test.

\begin{tabular}{|c|c|c|}
\hline List $1^{*}$ & List ${ }^{*}$ & List $3^{*}$ \\
\hline $\begin{array}{l}\text { È rimasto solo al mondo } \\
\text { leri hai comprato poco latte } \\
\text { Francesca è incinta di nuovo } \\
\text { L'acqua bolle a cento gradi } \\
\text { II giornale contiene cattive notizie } \\
\text { La macchina funzionava con difficoltà } \\
\text { II tassista guida con prudenza } \\
\text { Stamattina sono andato in banca } \\
\text { I| recinto separa i giardini } \\
\text { L'auto sbanda sempre in curva } \\
\text { II cameriere porterà le pizze } \\
\text { II mare era molto agitato } \\
\text { II compito è molto difficile } \\
\text { Le ciliegie maturano a giugno } \\
\text { II meccanico aggiusterà il motore } \\
\text { La ragazza aveva lunghi capelli } \\
\text { L'arrosto è cotto a puntino } \\
\text { All'alba spegnevano le luci } \\
\text { Pagherò il conto alla cassa } \\
\text { I| nonno dormiva due ore }\end{array}$ & $\begin{array}{l}\text { È scappato ieri dalla prigione } \\
\text { Milano ha un clima freddo } \\
\text { Gli ospiti sono arrivati già } \\
\text { II turista passeggia nel museo } \\
\text { II detersivo rovina la lana } \\
\text { Le stelle brillano in cielo } \\
\text { Oggi hanno camminato per ore } \\
\text { Domani balleremo fino a tardi } \\
\text { La minestra bolliva in pentola } \\
\text { Laura diceva bugie a tutti } \\
\text { La signora leggeva un libro } \\
\text { Le scale sono molto faticose } \\
\text { La partita inizierà in anticipo } \\
\text { II camino riscalda la stanza } \\
\text { II venditore mostra la merce } \\
\text { Dopo cena guardo la televisione } \\
\text { A destra troverai un portone } \\
\text { La povera moglie piangeva sempre } \\
\text { II nostro amore sarà eterno } \\
\text { II sole tramonta a occidente }\end{array}$ & $\begin{array}{l}\text { La nave scivola sulle onde } \\
\text { L'aquilone vola alto nel cielo } \\
\text { Certamente ha viaggiato in treno } \\
\text { II ristorante ha cambiato gestione } \\
\text { Gli operai lavorano nel cantiere } \\
\text { II fulmine ha colpito l'albero } \\
\text { Tremava ancora per la paura } \\
\text { I genitori sono molto apprensivi } \\
\text { Prepariamo la colazione alla mamma } \\
\text { II ponte passava sul fiume } \\
\text { II vino invecchia nelle botti } \\
\text { II direttore convoca la riunione } \\
\text { Laura insegnava inglese ai bambini } \\
\text { Ha amato una sola donna } \\
\text { II coro cantava una canzone } \\
\text { La ballerina danza con grazia } \\
\text { II parlamento discute le leggi } \\
\text { Spesso mangiamo con troppa fretta } \\
\text { I cittadini pagano le tasse } \\
\text { II fritto misto è pesante }\end{array}$ \\
\hline List 4\# & List $5^{\#}$ & List $6^{\#}$ \\
\hline  & $\begin{array}{l}\text { Porteremo un regalo alla nonna } \\
\text { I guanti proteggono le mani } \\
\text { Le forbici tagliano la carta } \\
\text { Ha cercato lavoro a lungo } \\
\text { La posta arriva in ritardo } \\
\text { Queste scarpe sono molto strette } \\
\text { La mamma abbraccia il bambino } \\
\text { La fermata dista cento metri } \\
\text { L'autobus partirà tra cinque minuti } \\
\text { Denuncia il furto alla polizia } \\
\text { Sveniva spesso per il caldo } \\
\text { Le ragazze seguono la moda } \\
\text { Le rose sbocciano a maggio } \\
\text { Dopo pranzo faccio un pisolino } \\
\text { II circo diverte i bambini } \\
\text { La signora comprò una pelliccia } \\
\text { La droga uccide molti giovani } \\
\text { I pellegrini iniziarono il viaggio } \\
\text { II padre era molto malato } \\
\text { Le patate crescono sotto terra }\end{array}$ & $\begin{array}{l}\text { Porteremo un regalo alla nonna } \\
\text { I pompieri spensero il fuoco } \\
\text { II frigorifero conserva i cibi } \\
\text { L'aeroplano volava fra le nuvole } \\
\text { II chirurgo ha operato d'urgenza } \\
\text { L'acqua bolle a cento gradi } \\
\text { Oggi hanno camminato per ore } \\
\text { L'aquilone vola alto in cielo } \\
\text { II treno partirà in ritardo } \\
\text { Ha cercato lavoro a lungo } \\
\text { II recinto separa i giardini } \\
\text { Milano ha un clima freddo } \\
\text { II fritto misto è pesante } \\
\text { La fermata dista cento metri } \\
\text { II vecchio era molto stanco } \\
\text { II compito è molto difficile } \\
\text { Dopo cena guardo la televisione } \\
\text { Ha amato una sola donna } \\
\text { Le ragazze seguono la moda } \\
\text { II cameriere apparecchia il tavolo }\end{array}$ \\
\hline
\end{tabular}

${ }^{*}$ Sentences used during the test

\# Sentences used during the re-test

Table II. Noise variation index from the 1st to the 5th triplet of sentences.

\begin{tabular}{lc} 
NUMBER OF CORRECT WORDS & NOISE VARIATION INDEX* \\
ANSWERED & \\
0 & $-5 \mathrm{~dB} \mathrm{HL}$ \\
1 & $-3 \mathrm{~dB} \mathrm{HL}$ \\
2 & $-1 \mathrm{~dB} \mathrm{HL}$ \\
3 & $+1 \mathrm{~dB} \mathrm{HL}$ \\
4 & $+3 \mathrm{~dB} \mathrm{HL}$ \\
5 & $+5 \mathrm{~dB} \mathrm{HL}$ \\
\hline
\end{tabular}

${ }^{*}$ Noise variation index changed depending on the number of correct words answered (all employed sentences were composed of 5 words). For example, if the number of correct words answered was 0 , then the noise presentation level of the next triplet was decreased of $5 \mathrm{~dB} \mathrm{HL}$.
Table III. Noise variation index from the 6th to the 20th triplet of sentences.

\begin{tabular}{lc} 
NUMBER OF CORRECT WORDS & NOISE VARIATION INDEX* \\
ANSWERED & \\
0 & $-2 \mathrm{~dB} \mathrm{HL}$ \\
1 & $-1 \mathrm{~dB} \mathrm{HL}$ \\
2 & $0 \mathrm{~dB} \mathrm{HL}$ \\
3 & $0 \mathrm{~dB} \mathrm{HL}$ \\
4 & $+1 \mathrm{~dB} \mathrm{HL}$ \\
5 & $+2 \mathrm{~dB} \mathrm{HL}$ \\
\hline
\end{tabular}

${ }^{*}$ Noise variation index changed depending on the number of correct words answered (all employed sentences were made up of 5 words). For example, if the number of correct words answered was 0 , then the noise presentation level of the next triplet was decreased of $2 \mathrm{~dB} H \mathrm{HL}$. 


\begin{tabular}{|c|c|c|c|c|c|c|c|c|c|c|c|c|}
\hline TRIPLET & SPEECH & NOISE & ANSWER & CORRECTION & SPEECH & NOISE & ANSWER & CORRECTION & SPEECH & NOISE & ANSWER & CORRECTION \\
\hline 1 & $\begin{array}{c}0,1534911 \\
55\end{array}$ & 45 & & -5 & $\begin{array}{c}0,790503 \\
65\end{array}$ & 55 & & -5 & $\begin{array}{c}0,121552 \\
75\end{array}$ & 65 & & -5 \\
\hline 2 & $\begin{array}{c}0,6865855 \\
75\end{array}$ & 60 & & -5 & $\begin{array}{c}0,65103 \\
55\end{array}$ & 40 & & -5 & $\begin{array}{c}0,160476 \\
65\end{array}$ & 50 & & -5 \\
\hline 3 & $\begin{array}{c}0,0085683 \\
75\end{array}$ & 55 & & -5 & $\begin{array}{c}0,055349 \\
55\end{array}$ & 35 & & -5 & $\begin{array}{c}0,042109 \\
65\end{array}$ & 45 & & -5 \\
\hline 4 & $\begin{array}{c}0,7952336 \\
55\end{array}$ & 30 & & -5 & \begin{tabular}{|c|}
0,93916 \\
75
\end{tabular} & 50 & & -5 & $\begin{array}{c}0,445441 \\
65 \\
\end{array}$ & 40 & & -5 \\
\hline 5 & $\begin{array}{c}0,7115584 \\
75\end{array}$ & 45 & & -5 & $\begin{array}{c}0,469677 \\
55\end{array}$ & 25 & & -5 & $\begin{array}{c}0,499572 \\
65\end{array}$ & 35 & & -5 \\
\hline
\end{tabular}

Fig. 1. Calculation sheet example from the 1 st to the 5 th triplet.

SPEECH: it refers to the speech material presentation intensities ( $55 \mathrm{~dB} \mathrm{HL}, 65 \mathrm{~dB} \mathrm{HL}, 75 \mathrm{~dB} \mathrm{HL}$ )

NOISE: it provides the noise of competition level that changes depending on the accuracy of the preceding response

ANSWER: it represents the number of correct words answered

CORRECTION: it provides the noise variation index that is applied to the next corresponding noise level.

The technological setting was composed of two loudspeakers, a clinical audiometer Biomedica-Amplifon Interacoustics AC $40^{\circledR}$ and a power amplifier Interacoustics AP70®. To facilitate administration of the test, an automated computer controlled procedure was developed using an Excel calculation sheet (Fig. 1).

\section{Statistical analysis}

To determine the repeatability and consistency of SRTs measured over time, test-retest reliability was calculated, using Spearman`s Rho-correlation. To verify whether age has an influence on the overall measured mean SRT value, univariate analysis of variance (ANOVA) was performed.

\section{Results}

The mean results obtained through the test and re-test were calculated considering each employed intensity; subsequently, overall test + re-test outcomes were analysed (Table IV). The overall mean SRT value was
-13.3 dB HL (standard deviation: 0.64; minimum value -14.6 dB HL; maximum value $-12.1 \mathrm{~dB} \mathrm{HL}$ ) and was calculated at the end of both test and re-test, with respect to all SRT values for each intensity examined. The low standard deviation measured (close to 0 ) suggested that the mean SRT value was highly indicative of each listener's performance. Statistical analysis showed a significant relationship between the overall mean SRT of the test and the overall mean SRT of the re-test $(r=0.496$; $\mathrm{p}<0.001$ ), confirming the repeatability and consistency of SRTs measured over time. However, when comparing the different levels between the test and the re-test, a significant relationship between the test and the re-test was found at $65 \mathrm{~dB}$ HL $(r=0.366 ; p=0.009)$ and at $75 \mathrm{~dB}$ HL ( $r=0.362 ; p=0.010)$, but no significant relationship was found at $55 \mathrm{~dB}$ HL between the test and re-test $(r=0.176 ; p=0.223)$. The results of univariate ANOVA showed that age significantly affected overall mean SRT $(F=4.500 ; p=0.039$ ) (Fig. 2).

Table IV. SRT Results.

\begin{tabular}{|c|c|c|c|c|c|c|c|c|c|c|c|c|}
\hline & \multicolumn{3}{|c|}{ TEST } & \multicolumn{3}{|c|}{ RE-TEST } & \multicolumn{6}{|c|}{ TEST \& RE-TEST* } \\
\hline & $\begin{array}{l}\text { SRT } 55 \\
\text { dB HL }\end{array}$ & $\begin{array}{l}\text { SRT } 65 \\
\text { dB HL }\end{array}$ & $\begin{array}{l}\text { SRT } 75 \\
\text { dB HL }\end{array}$ & $\begin{array}{c}\text { OVERALL } \\
\text { TEST } \\
\text { SRT }\end{array}$ & $\begin{array}{l}\text { SRT } 55 \\
\text { dB HL }\end{array}$ & $\begin{array}{l}\text { SRT } 65 \\
\text { dB HL }\end{array}$ & $\begin{array}{l}\text { SRT } 75 \\
\text { dB HL }\end{array}$ & $\begin{array}{l}\text { OVERALL } \\
\text { RETEST } \\
\text { SRT }\end{array}$ & $\begin{array}{l}\text { SRT } 55 \\
\text { dB HL }\end{array}$ & $\begin{array}{l}\text { SRT } 65 \\
\text { dB HL }\end{array}$ & $\begin{array}{l}\text { SRT } 75 \\
\text { dB HL }\end{array}$ & $\begin{array}{l}\text { OVERALL } \\
\text { TEST- } \\
\text { RETEST } \\
\text { SRT }\end{array}$ \\
\hline MEAN & -13.69 & -14.97 & -9.56 & -12.74 & -14.78 & -16.00 & -10.72 & -13.84 & -14.24 & -15.49 & -10.14 & -13.29 \\
\hline MEDIAN & -13.65 & -15.10 & -9.58 & -12.57 & -14.90 & -16.05 & -10.75 & -13.75 & -14.20 & -15.48 & -10.10 & -13.24 \\
\hline $\begin{array}{l}\text { STANDARD } \\
\text { DEVIATION }\end{array}$ & 1.07 & 0.98 & 0.88 & 0.75 & 0.97 & 0.88 & 1.12 & 0.72 & 0.80 & 0.76 & 0.80 & 0.64 \\
\hline MINIMUN & -15.90 & -17.15 & -11.75 & -14.38 & -17.10 & -17.65 & -13.90 & -15.45 & -16.38 & -17.28 & -11.80 & -14.61 \\
\hline MAXIMUM & -11.50 & -12.85 & -7.65 & -11.65 & -12.50 & -13.10 & -6.95 & -12.58 & -12.53 & -13.43 & -7.65 & -12.13 \\
\hline
\end{tabular}

${ }^{*}$ Final mean outcomes were calculated at the end of both test and re-test, with respect to all SRT values for each intensity examined. 


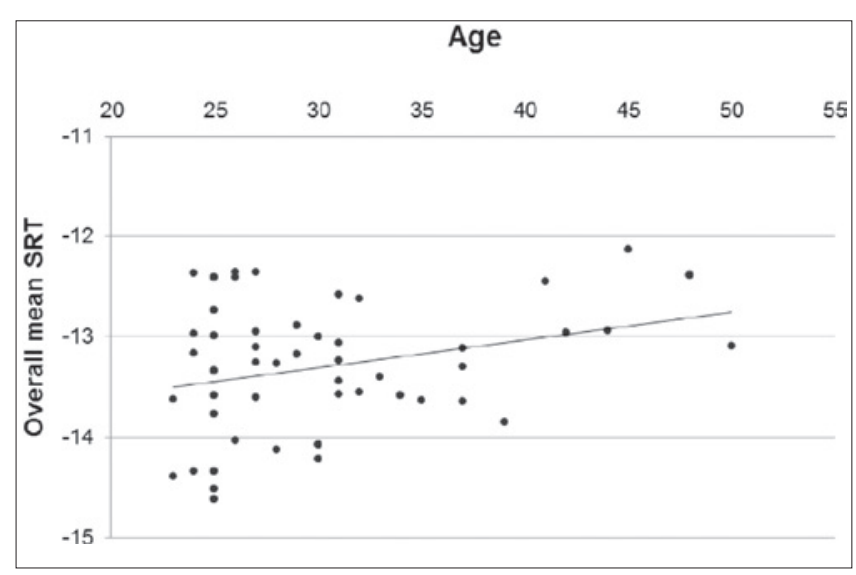

Fig. 2. Age influence on the overall mean SRT values.

\section{Discussion}

Over the past decades, advances in audiological research have improved to such an extent that they have considerably and truly changed patients' lives. Furthermore, the evolution of traditional hearing aids and the birth of total or semi-implantable hearing devices have led the clinician to re-evaluate the approach to clinical practice. The necessity to understand whether a certain patient could benefit from the current hearing technology, as well as quantitatively determining the functional improvement levels, has promoted the integration of better hearing diagnostic methods for the purpose of further exploration of the complexity of the auditory system functions. Being too far from reality, conventional investigations of hearing loss based on pure-tone threshold audiometry and on mono/disyllabic word lists presented in quiet conditions have been shown to be inadequate ${ }^{5}$. The lack of information derived from traditional test battery is typically relevant if we consider the "cocktail-party" problem, hence the loss of SNR score in patients with hearing disorders ${ }^{422}$. In particular, the loss of spectro-temporal acoustic resolution related to cochlear hair cell dysfunctions determines a reduction of speech intelligibility that is easily detectable in noisy environments ${ }^{23}$. Sentence-type speech-in-noise tests have been conceived to explore speech communication in noise at a fixed or varied SNR and currently have become part of the international basic audiological assessment ${ }^{36-141619}$. Moreover, to avoid floor and ceiling effects that may influence the validity of results for fixed SNR tests, adaptive speech-in-noise tests have been applied ${ }^{1718}$. The SNR score at which $50 \%$ of the sentences are repeated correctly (SRT) represents an alternative of percent intelligibility to measure speech intelligibility when the intensity level of either the speech or the noise is varied. Speech items are composed of daily sentences as the mono/disyllabic words lack information redundancy, which may not be adequate to trigger the signal processing features of hearing technologies ${ }^{9}$. The literature reports several studies that have been carried out to point out the real benefits related to hearing device rehabilitation. Bovo et al. ${ }^{15}$ evaluated the effect of bone-anchored hearing aid simulators in subjects with acquired unilateral sensorineural hearing loss. In particular, the authors tested the SRT changes in relation to different speech source positions, with a background of diffuse noise. Outcomes highlighted a lack of efficacy of bone-anchored hearing aid simulators in discriminating speech sources located in different acoustic settings. Beltrame et al. ${ }^{24}$ showed the auditory results of the Vibrant Soundbridge coupled with the round windows in patients with mixed hearing loss. The measurements of aided SRT in background noise of 55 and $70 \mathrm{~dB}$ SPL documented only a slight increase compared with normal reference data.

Among adaptive sentence-type speech-in-noise tests cited in literature, the introduction of roving-level tests may represent an additional and useful tool in speech intelligibility investigation ${ }^{20}$. It is notorious that each hearing device performs differently at different sound pressure levels in relation with its own specific input dynamic range. Furthermore, in everyday speaking conditions speech and noise signals change independently of one another. A roving-level adaptive test employs target and competing signals varying in level to mimic everyday life speaking conditions and to explore a more complete sound range. Haumann et al. recently analysed a relative homogeneous sample of 55 cochlear implant (CI) users with different CI systems submitted to fixed and roving-level adaptive level tests. When a fixed-level method was applied, the groups using different devices reached very similar outcomes. On the other hand, remarkable changes were recorded employing roving-level adaptive tests that are able to detect the effects of CI processors on everyday speech perception ${ }^{20}$. In our personal experience, the roving condition concerned three different speech material intensities (55 dB HL, $65 \mathrm{~dB}$ HL, $75 \mathrm{~dB} \mathrm{HL}$ ) and as a consequence three different mean SRT values were analysed. Speech messages were randomly roved while noise level varied depending on the accuracy of the preceding response until the subject repeated $50 \%$ of the speech signal correctly. The final mean value was $-13.3 \mathrm{~dB}$ HL (standard deviation: 0.64 ; minimum value $-14.6 \mathrm{~dB}$ HL; maximum value $-12.1 \mathrm{~dB} \mathrm{HL}$ ) and was calculated at the end of both the test and re-test, with respect to all SRT values for each intensity examined. In particular, the population repeated $50 \%$ of the presented speech material correctly, when the confounding signal was overcoming the speech message of $13.3 \mathrm{~dB}$ HL. It is plausible that a normal hearing Italian adult submitted to the test obtains a result ranging from $-14.6 \mathrm{~dB}$ HL to $-12.1 \mathrm{~dB} \mathrm{HL}$, although Italian listeners with hearing impairment will probably show a SRT score worse than $-12.1 \mathrm{~dB}$ HL. As far as the literature is concerned, each of the 50 subjects evaluated achieved better results during the re-test probably due to the cognitive 
gain achieved in the preceding test ${ }^{25}$. Statistical analysis showed a significant relationship between the overall mean SRT of the test and the overall mean SRT of the retest $(r=0.496 ; p<0.001)$, confirming the repeatability and consistency of SRTs measured over time. However, when comparing the different levels examined between the test and re-test, no significant relationship was found at $55 \mathrm{~dB}$ HL between the test and re-test $(r=0.176 ; p=0.223)$. This result may be explained by a strong learning effect (much better performances during the re-test in comparison with the test) during the presentation level of $55 \mathrm{~dB}$ HL. The results of the univariate ANOVA showed that age significantly affected the overall mean SRT, despite the fact that this study did not include elderly subjects (age ranged between 23 and 50 years). Younger subjects achieved meaningfully better SRTs values demonstrating age as a relevant influencing factor on the hearing processing under conditions of noise (Fig. 2). Current literature describes the development of many adaptive SNR tests and their comparison is actually challenging because of several procedural aspects that may influence outcomes ${ }^{25}$ : - different language adoption with respect to a large number of speech audiological parameters: number of syllables/words, word frequency, sentence redundancy, understandable or meaningless sentences, list length, pronunciation, breaks between sentences;

- different noise presentation modes: noise masking type, continuous/fluctuating/synchronous noise delivering;

- different environment parameters: booth dimensions, type of soundproofing, use of headphones/speakers, number of speakers, distance between patient and speaker;

- different adaptive SNR test features: starting SNR presentation level, fixed element (speech or noise?), intensity of the fixed signal, adaptive method (signal change criteria according to tester answers), re-test execution, use of visual aids;

- different sample enrollment; number of listeners, nationality, age, education level, comorbidities.

In fact, despite the rather innovative aspects of adaptive speech intelligibility tests, they still have some limits:

- the extreme procedural variability does not allow an international comparison of SRT outcomes;

- paediatric age, education level and native language may highly influence correct performance of the test;

- the need for a relatively long execution time may condition the feasibility of adaptive tests during daily clinical practice.

\section{Conclusions}

We introduced a novel Italian roving-level adaptive test to obtain normative data in healthy Italian adults. The adoption of roving-level tests may represent an additional and useful tool in speech intelligibility investi- gation to quantify the actual benefits related to hearing rehabilitation devices (which hearing device? when to prescribe it?) in acoustic conditions simulating everyday life.

\section{References}

1 Prosser S, Pulga M, Mancuso A, et al. Speech perception with hearing aids: effects of noise reduction and directional microphone systems on amplified signals. Audiol Med 2009;7:106-11.

2 Taylor B. Speech-in-noise tests: how and why to include them in your basic test battery. Hear J 2003;56:40-3.

3 Nilsson M, Soli SD, Sullivan JA. Development of the hearing in noise test for the measurement of speech reception thresholds in quiet and in noise. J Acoust Soc Am 1994;95:1085-99.

4 Cherry E. Some experiments on the recognition of speech with one and with two ears. J Acoust Soc Am 1953;25:975-9.

5 Walden BE, Scwartz DM, Williams DL, et al. Tests of the assumption underlying comparative hearing aid evalutations. J Sp Hear Dis 1983;48:264-73.

6 Nielsen JB, Dau T. Development of a Danish speech intelligibility test. Int J Audiol 2009;48:729-41.

7 Luts H, Boon E, Wable J, et al. FIST: a French sentence test for speech intelligibility in noise. Int J Audiol 2008;47:373-4.

8 Vainio M, Suni A, Jarveläinen H, et al. Developing a speech intelligibility test based on measuring speech reception thresholds in noise for English and Finnish. J Acoust Soc Am 2005;118:1742-50.

9 Wong LL, Soli SD. Development of the Cantonese hearing in noise test (CHINT). Ear Hear 2005;26:276-89.

10 Soli SD, Vermiglio A, Wen K, et al. Development of the Hearing In Noise Test (HINT) in new languages. In: Short course presented at the $14^{\text {th }}$ Convention of the American Academy of Audiology. Philadelphia, PA 2002.

11 Hagerman B. Clinical measurements of speech reception threshold in noise. Scand Audiol 1984;13:57-63.

12 Laurence RF, Moore BC, Glasberg BR. A comparison of behind-the-ear high-fidelity linear hearing aids and two-channel compression aids in the laboratory and in everyday life. Br J Audiol 1983;17:31-48.

13 Hagerman B. Sentences for testing speech intelligibility in noise. Scand Audiol 1982;11:79-87.

14 Plomp R, Mimpen AM. Improving the reliability of testing the speech reception threshold for sentences. Audiology 1979; 18:43-52.

15 Bovo R, Prosser S, Ortore RP, et al. Speech recognition with BAHA simulator in subjects with acquired unilateral sensorineural hearing loss. Acta Otolaryngol 2011;131:633-9.

16 Dietz A, Buschermöhle M, Aarnisalo AA, et al. The development and evaluation of the Finnish Matrix Sentence Test for speech intelligibility assessment. Acta Otolaryngol 2014;134:728-37.

17 Brand T, Kollmeier B. Efficient adaptive procedures for threshold and concurrent slope estimates for psychophysics and speech intelligibility tests. J Acoust Soc Am 2002;111:2801-10. 
18 Noordhoek IM, Houtgast T, Festen JM. Measuring the threshold for speech reception by adaptive variation of the signal bandwidth. I. Normal-hearing listeners. J Acoust Soc Am 1999;105:2895-902.

19 Ciorba A, Zattara S, Loroni G, et al. Quantitative enhancement of speech in noise through a wireless equipped hearing aid. Acta Otorhinolaryngol Ital 2014;34:50-3.

20 Haumann S, Lenarz T, Büchner A. Speech perception with cochlear implants as measured using a roving-level adaptive test method. ORL J Otorhinolaryngol Relat Spec 2010;72:312-8.

21 Cutugno F, Prosser S, Turrini M. Audiometria vocale - vol. III. First edition. Padova: GN. Resound 2005.
22 Killion MC. SNR loss: I can hear what people say, but I can't understand them. Hear Rev 1997;4:8-14.

23 Moore BCJ. Perceptual consequences of cochlear hearing loss and their implication for the design of hearing aids. Ear Hear 1996;17:133-60.

24 Beltrame AM, Martini A, Prosser S, et al. Coupling the Vibrant Soundbridge to cochlea round window: auditory results in patients with mixed hearing loss. Otol Neurotol 2009;30:194-201.

25 Wagener KC, Brand T. Sentence intelligibility in noise for listeners with normal hearing and hearing impairment: Influence of measurement procedure and masking parameters. Int J Audiol 2005;44:144-56.

Received: March 4, 2016 - Accepted: July 28, 2016

Address for correspondence: Pietro Canzi, Department of Otorhinolaryngology, IRCCS Policlinico San Matteo Foundation and University of Pavia, viale Camillo Golgi 19, 27100 Pavia, Italy. Fax +390382 528184. E-mail: pietro.canzi@unipv.it 